\title{
Ana Dili Türkçe Olmayan Öğrencilerde Okul Öncesi Eğitimin İlk Okuma Yazma Sürecine Etkisi
}

\author{
The Effect of Pre-school Education on the Process of Initial Literacy \\ for Non Native Turkish Students \\ Fatma SUSAR KIRMIZI*, Hatice BOZTAS ${ }^{* * *}$, Emel SALGUT ${ }^{* * *}$, \\ Duygu ÇAĞ ADIGÜZELL ${ }^{* * * *}$, Alper KOÇ***** \\ - Geliş Tarihi: 08.01.2019 • Kabul Tarihi: 09.05.2019 • Çevrimiçi Yayın Tarihi: 21.06.2019
}

\section{Öz}

$\mathrm{Bu}$ araştırmanın amacı öğretmen görüşlerine göre anadili Türkçe olmayan ve okul öncesi eğitim almamış öğrencilerin ilk okuma yazma öğrenme sürecinde yaşadığı sorunları tespit etmektir. Araştırmanın gerçekleştirilmesinde karma yöntemlerden "gömülü desen" tercih edilmiştir. Verilerin elde edilmesinde araştırmacılar tarafindan geliştirilmiş olan "açı uçlu soru anketi" ve "Ana Dili Türkçe Olmayan Öğrencilerde Okul Öncesi Eğitimin İlk Okuma Yazma Öğrenme Sürecine Etkisine İlişkin Öğretmenlerin Eğilimleri Ölçeği (ADİLKÖ)" ölçeği kullanılmıştır. Araştırmanın nicel boyutu 176 öğretmen; nitel boyutu ise 35 öğretmenle gerçekleştirilmiştir. Nitel verilere uygulanan içerik çözümlemesi sürecinde "uyum aşaması, görsel okuma, kendini ifade etme, yönergelerin anlaşılması, yazma becerisi" temalarına ulaşılmıştır. Öğretmenlerden 15 'i okul öncesi eğitimin ana dili Türkçe olmayan öğrencilerin hazır bulunuşluk düzeyine olumlu etkilerinin olduğunu belirtmiştir. Okul öncesi eğitim alan öğrencilerin ilk okuma yazma öğrenme başarılarına ilişkin öğretmen algıları onların sınıf mevcutlarına ve görev yerlerine göre anlamlı bir farklılık göstermemektedir.

Anahtar sözcükler: anadili Türkçe olmayan öğrenciler, öğrenci, öğretmen, ilk okuma yazma, okul öncesi eğitim, ilkokul.

Atıf:

Susar Kırmızı, F., Boztaş, H., Salgut, E., Çağ Adıgüzel, D. ve Koç, A. (2020). Ana dili türkçe olmayan öğrencilerde okul öncesi eğitimin ilk okuma yazma sürecine etkisi. Pamukkale Üniversitesi Ĕgitim Fakültesi Dergisi, 48, 105-129. doi: 10.9779/pauefd.509817

\footnotetext{
* Prof. Dr., Pamukkale Üniversitesi, Eğitim Fakültesi, ORCID: 0000-0002-0426-1908, fsusar@pau.edu.tr

** Yük. Lis. Öğr., Pamukkale Üniversitesi, Eğitim Bilimleri Enstitüsü, 0000-0002-1747-9965, hatic_boztas@hotmail.com

*** Yük. Lis. Öğr., Pamukkale Üniversitesi, Eğitim Bilimleri Enstitüsü, ORCID: 0000-0003-3391-3351, slgt_emel@hotmail.com

**** Yük. Lis. Öğr., Pamukkale Üniversitesi, Eğitim Bilimleri Enstitüsü, 0000-0002-3360-6776, duygucag@gmail.com

****** Yük. Lis. Öğr., Pamukkale Üniversitesi, Eğitim Bilimleri Enstitüsü, 0000-0002-3439-6069,

alper_koc43@hotmail.com
} 


\begin{abstract}
The purpose of this research is to determine the problems experienced in the learning process of initial literacy by the students that are non-Turkish and do not have pre-school education according to the views of the teachers. "Grounded design" among the mixed methods was conducted in processing the research. The" open-ended question questionnaire" and the "Scale for Tendency of Teachers towards Effect of Pre-school Education on Learning Process of Initial Literacy for Non-Turkish Students (STTEPL)" generated by the researchers were implemented in collecting data. The quantitative dimension of the study was carried out with 176 teachers, and the qualitative dimension was conducted with 35 teachers. The themes of "adaptation phase, visual reading, self-expression, understanding the instructions, and writing skill were acquired in the process of content analysis applied to the qualitative data. 15 of the teachers mentioned that the pre-school education were of positive effects on the readiness level of non-Turkish students. Perceptions of the teachers about the success of the students with pre-school education do not significantly vary in terms of the variables of classroom size, and place of duty of the teachers.
\end{abstract}

Keywords: non native Turkish Student, teacher, initial literacy, pre-school education, primary school.

\title{
Cited:
}

Susar Kırmızı, F., Boztaş, H., Salgut, E., Çă̆ Adıgüzel, D. \& Koç, A. (2020). The effect of pre-school education on the process of initial literacy for non native Turkish students. Pamukkale Üniversitesi Ĕ̈itim Fakültesi Dergisi, 48, 105-129. doi: 10.9779/pauefd.509817 


\section{Giriş}

İnsanlar varoluşlarından bu yana birbirleriyle iletişim halindedir. $\mathrm{Bu}$ iletişimin gerçekleşebilmesi için kullanılan en etkili araçlardan biri de dildir. İletişim aracı olarak kullanılan diller de birbirleriyle etkileşim halinde olan dinamik yapılardır. Farklı kültürlerden gelen insanların iletişim için birden fazla dil kullanması bu etkileşimin gerçekleşmesini sağlamaktadır.

Etkili kullanılan dil etkili düşünen birey demektir. Dil, zihinsel gelişimin ve anlamanın aracıdır. Dolayısıyla dil, bireyin bilişsel ve sosyal gelişiminde önemli bir yere sahiptir ve insanların ilk öğrendikleri dil ana dilleridir (Yapıcı, 2004; Özbay ve Melanlığlu, 2008). "Anadil bireyin ilk öğrendiği ve kullandığı; kişiliğinin bir parçası olarak gördüğü ve temel toplumsal ilişkilerinde iletişim aracı olarak başvurduğu dildir" (Tsitselikés, 1995, akt. Achmet, 2005, s. 36). Dil çocuklara aktarılan önemli bir mirastır. Aile bireyleri ve okul öncesi uzmanları anadilin korunmasında ve gelişmesinde önemli bir role sahiptir. Anadil, insanın duygu ve düşüncelerini en güzel biçimde anlattığ1 dildir (Parlak, 2014; Aytaş ve Çeçen, 2010). Birey anadilini işiterek, yaşayarak, anne-baba ve yakın çevresinden öğrenir. Daha sonrada tüm yaşamı boyunca kullanır (Demirel, 1999, s.12) yani anadil edinimi aile ortamından çevreye doğru genişleyen, bireyin doğumundan itibaren kendiliğinden oluşan ve her şeye rağmen gerçekleşen bir süreçtir. Bu süreç eğitim-öğretimde de göz ardı edilmemelidir. Anadil eğitimi ve öğretimini yakın ve uzak çevreden edinilen öğrenme sürecinin daha düzenli, daha etkin ve daha güzel olması için gelişmelere doğrudan müdahale etmek ve uygun etkinlikler düzenlemektir. Çocukların nesneleri tanımaları, adlandırmaları anadilinde başlamaktadır. Dolayısıyla anadil kullanım becerilerinin düzeyi anlama, muhakeme etme, problem çözme gibi zihinsel süreçlerinin gelişmesinde önemli bir etkendir (Demir ve Yapıc1, 2007). Ancak bazı durumlarda birey iki dillilik yaşayabilmektedir. İki dillilik (bilingualism), iki farklı dilde iletişim kurabilme becerisi anlamına gelmektedir. Birey doğduğu andan itibaren iki farklı dil konuşulan ortamda büyüyen çocuklar olağan bir şekilde her iki dili kullanabilme yetisini geliştirmektedir.

\section{İki Dillilik}

İki dillik kavramında ortak bir kanıya ulaşılamamasına rağmen bazı araştırmacıların tanımlarına bakıldığında belli ortak noktalar etrafında değişik tanımlar yapıldı̆̆ görülmektedir. $\mathrm{Bu}$ tanımlara bakılacak olursa iki dilin alternatif şekilde kullanım pratiğine iki dillilik ve bunu uygulayan kişiye de iki dilli denmektedir. İki dilliği bir dili akıcı bir şekilde kullanırken diğer dilde tam olarak anlamlı ifadeler üretilmesidir şeklinde tanımlamıştır.

Tüm toplumlarda birden fazla etnik grup olduğu için dünyada hiçbir toplum homojen değildir. Çünkü belli bir topluma mensup insanlar farklı kültüre, farklı dillere ve farklı inançlara sahip insanlarla bir arada yaşamaktadır. Medeniyetler beşiği olan Türkiye'de de durum aynıdır. Ermeniler, Lazlar, Kürtler, Araplar, Zazalar ve Müslüman olan ya da olmayan gruplar bir arada yaşamaktadır (Aka, 2012; Yılmaz ve Şekerci, 2016). Anadolu coğrafyası farklı kültürleri kardeşlik çatısında bir arada bulundurmaktadır. Diğer taraftan Türkiye'de konuşulan dillere göç gibi nedenlerle gelenlerin dilleri de eklenince konuşulan dil sayısı artmaktadır. Buna bağlı olarak resmi dil ile çocuğun ana dilinin farklı olması zaman zaman sorun olabilmektedir. Özellikle ilk okuma yazma öğretimi sürecinde farklı sorunlar ortaya çıkabilmektedir. Dahası 
Türkçe'nin az konuşulduğu bölgelerde birçok öğrenci okula Türkçe bilmeden ya da az bilerek başlamaktadır. Buna karşın eğitim sürecinde öğretmenin ve öğrencinin yaşadığı sıkıntılar başta MEB ve kamuoyu tarafindan maalesef pek de dikkate alınmamıştır. Türkçeyi az bilen öğrenciler, eğitim öğretim sürecinde öğretmenleri ve arkadaşlarıyla sağlıklı iletişim kuramadıklarından gerek okul yaşamlarında gerekse okullarından mezun olduktan sonra birçok sorun yaşamışlardır. Bu öğrencilerin birçoğunun eğitim öğretim sürecinin belli aşamalarında akranlarından geri kaldıkları, gerekli önlemler alınmadığında yeterli başarıya ulaşamadıkları ve okulu terk ettikleri görülmektedir (Taşkaya, 2017). Öğrencilerin Türkçeyi etkili bir şekilde kullanması onların sağlıklı bir iletişim becerisi geliştirmesinde etkili olmaktadır. Ana dili Türkçe olmayan öğrenciler Türkçe’yi iyi öğrendiklerinde konuşma, yazma ve okuma konusunda da iyi bir noktaya gelebilmektedir.

Önemsenmesi gereken diğer bir konu ise milli sınırlar içerisinde yaşayan ve vatandaşlık bağı ile Türkiye Cumhuriyeti Devleti'ne bağlı olan her yurttaşın Türkçeyi iyi bir şekilde bilmesi gerektiğidir. Çünkü bu ülkede yaşayan herkesin sosyal, siyasal, külttürel ve ekonomik hayata en geniş anlamıyla katılabilmesi resmî dil olan Türkçe'nin yeterli ölçüde bilinip kullanılmasına bağlıdır (Calp, 2003, s.313).

Şimşek Bekir ve Temel'e (2006) göre iki dillilik, bireylerin her iki dilde de hayatlarındaki bütün önemli alanlarında ihtiyaçlarını karşılayabilmeleridir. Genel bir tanımıyla iki dillik, bireyin ana dili dışındaki bir dili akıcı ve alternatif bir şekilde konuşma, okuma yazma ve anlama boyutunda bir iletişim aracı olarak kullanması ve bir dilden diğer bir dile ihtiyaçlarını karşılamak için geçiş yapabilmesidir (Butler \& Hakuta, 2004; Şimşek Bekir ve Temel, 2006; Tulu, 2009; Alıc1, 2012).

\section{İlk Okuma Yazma Öğretimi ve Okul Öncesi Eğitimin Önemi}

Bireyler doğdukları andan itibaren ölene kadar sürekli öğrenmekte; gelişim ve değişim göstermektedirler. Yaşam boyu devam eden eğitim öncelikle ailede başlar. Okul öncesi eğitim ise eğitim öğretim sürecinin ilk resmi basamağıdır. Çocukların zengin öğrenme deneyimleriyle sağlıklı büyümelerini ve ilk sosyal ortamlarında kendilerini gerçekleştirmelerini sağlar.

Okul öncesi, çocuğun gelişiminin en kritik dönemlerden biridir. Geçmiş yıllarda yapılan araştırma sonuçlarına bakıldığında, 0-6 yaş döneminde kazanılan davranışların bireyin kişiliğinin, alışkanlıklarının, değer ve ahlak yapısının temelini oluşturduğu görülmektedir (Tuğluk, Kök, Koçyiğit, Kaya ve Gençdoğan, 2008). Bloom tarafından yapılan araştırmaya göre 17 yaşına kadar süren zihinsel gelişimin \%50'sini 4 yaşına kadar, \% 30'unu 4 yaşından 8 yaşına kadar ve geri kalan \% 20'sini ise 17 yaşına kadar tamamlamaktadır (Fidan Erden 2002, akt: Ekinci Vural, 2012). Bu nedenle okul öncesi eğitimin bireyin hayatındaki önemi yadsınamaz.

Okulöncesi dönemde ilköğretim için gerekli temel beceriler kazanılmaktadır. Bu temel beceriler eğitimin daha sonraki aşamalarında çocukların akademik başarılarının artırmasını sağlamaktadır. Çocuğun ilköğretim döneminde kazanması gereken en temel becerilerden biri okuma ve yazma öğrenmesidir. Okulöncesi dönemde günlük yaşam içerisinde karşılaşılan olaylar ve çevredeki uyaranlar yardımıyla çocuklar okuma yazma ile ilgili ilk bilgileri kazanırlar. Bu şekilde okulöncesi dönem çocuğun okuma ve yazma ile ilgili pek çok deneyim kazanmasını sağlar. $\mathrm{Bu}$ deneyimler daha sonraki okul yaşantısı için temel oluştururlar (Entwisle, 1995; Margetts, 2003; Yoleri ve Tanış, 2004; Deretarla Gül ve Bal 2006; Yapıcı ve Ulu, 2010). Okul öncesi eğitimin çocuğun akademik başarısını olumlu etkilediği, aynı zamanda 
erken okulu bırakma isteği ve daimi başarısızlık olasılığını düşürdüğü de tespit edilmiştir. Bu nedenle okul öncesi eğitim, öğrencinin erken okul başarısızlığı ve bunun uzun süreçli sonuçlarını engellemek amacıyla başarılı bir tedbir olarak görülmektedir (Berlinski, Galiani \& Manacorda, 2008).

1962 yılında ilk kez “Anaokulları ve Ana Sınıfları Yönetmeliği” yürürlüğe konulmuş, daha sonra konu İkinci Beş Yıllık Kalkınma Planında şu cümlelerle yer almıştır: "Okul öncesi eğitimi 3-6 yaş çocuklarının eğitimdir. Bu eğitim, ancak anne eğitiminden yoksun çocukları ele alacaktır." 1973 yılında yürürlüğe giren 1739 sayılı Millî Eğitim Temel Kanunu ile Türk Millî Eğitim Sisteminin genel yapısı içinde okul öncesi eğitime, örgün eğitim sistemi içerisinde yer verilmiştir. Türkiye'de okul öncesi eğitim çalışmalarının daha koordineli bir şekilde gerçekleştirilebilmesi ve toplumda giderek artan gereksinime yanıt verilebilmesi için 1992 yılında Millî Eğitim Bakanlığı bünyesinde bir Okul Öncesi Eğitim Genel Müdürlüğü kurulmuştur (Oktay, 2002; Oktay, 2003; Yılmaz, 2003; Şahin, Susar Kırmızı ve Salgut, 2016). Okulöncesine ilişkin ilk düzenli programın 1989 yılında yayınlandı̆̆ 1 görülmektedir. Söz konusu program 4-5 yaş çocuklarının devam ettikleri anaokulları, anasınıfları ve uygulama sınıflarına yöneliktir. Daha sonra 1994 yılında yeniden düzenlenerek farklı bir boyut kazanan programda konu merkezli yaklaşım yerine çocuk merkezli yaklaşıma vurgu yapılmıştır. Bu programda, yaparak-yaşarak öğrenme ilkesi temele ön plana çıkarılmış ve çocukların gelişimi bütünsel olarak ele alınmıştır. 2002 yılında gözden geçirilerek yeni düzenlemelere gidilen Okul Öncesi Eğitim Programında konular veya üniteler programdan çıkarılmıştır. Konular ve üniteler yerine "hedefler" merkeze alınmış ve daha esnek bir program ortaya konulmuştur (Sapsağlam, 2013; Şahin, Susar Kırmızı ve Salgut, 2016). Okul Öncesi Eğitim Programı; 2006 yılında hazırlanarak 2012-2013 öğretim yılına kadar Okul Öncesi Eğitiminin Güçlendirilmesi Projesi kapsamında mevcut durum çözümlemeleri dikkate alınarak geliştirilmiştir. Bu programa göre; okuma yazmaya hazırlık çalışmaları ilkokula hazırlık çalışmalarının içerisinde yer alan ve çocukların ilkokula geçişini kolaylaştırmak, hazır bulunuşluk düzeylerini artırmak amacıyla yapılan etkinliklerdir. Kesinlikle okuma veya yazma öğretmek amacını taşımamaktadır. Programda okuma ve yazma öğretimi yoktur. Harfleri göstermek ve harfleri yazdırmak da yoktur (MEB, 2013).

Erken okuryazarlık becerileri çocuğun gelecekteki ilk okuma yazma eğitimi ve okul başarısı için çok önemlidir. Dil ve erken okuryazarlık birbiri ile yakından ilişkilidir. Okuma yazmadan farklı olan erken okuryazarlık, özellikle okul öncesi dönemde dil becerilerini geliştirmeye yönelik eğitim programları ile desteklenmekte ve çocukların gelecekteki okuryazarlık başarılarında önemli rol oynamaktadır. Çocukların harfleri öğrenmelerini hedefleyen programlar yerine sınıf içinde uyaklı sözcüklerden oluşan şarkılar söylenmesini ve seslerin sözcük içindeki konumlarına dayalı oyunlar oynanmasını destekleyen programlar onlara anlamlı deneyimler sağlar (MEB, 2013). Okul öncesi dönemde kazanılmış bu anlamlı okuma yazma deneyimleri çocukların sesleri hissetmelerini ve tanımalarını sağlar. Böylece ilk okuma yazma öğretiminde büyük önem taşıyan temel hazır bulunuşluk becerileri en üst seviyeye taşınmış olur.

Okul öncesi dönemde çocuk okuma gelişimi üzerinde etkili olan işitsel ayrımlaştırma becerisini kazanmaktadır. Bu beceriye sahip olan bir çocuk, harf ve kelimelerin söylenişlerini kavrar; kelimelerin başlangıç ve bitişlerindeki ses farklılıklarını ayırt eder; kelimelerin 
söylenişlerine ilişkin oyunlardan hoşlanır; kendisine okunan şiirleri ve hikâyeleri dinlemekten zevk duyar (Tuğluk, Kök, Koçyiğit, Kaya, ve Gençdoğan, 2008). Çocuğun dil ve zihin gelişiminin oldukça hızlı olduğu bu dönemde yapılan etkinlikler konuşma becerisinin gelişimini desteklerken, sözcük dağarcığını arttırmakta, kendini ifade etmesini kolaylaştırmaktadır. Yapılan çalışmalar çocuğu temel eğitime hazırlamakta ve okumaya ilişkin hazır bulunuşluk düzeyini arttırmaktadır. Böylece çocuğun okuma yazma öğretimine ilişkin ilgisi artabilmektedir.

Dil gelişimi ve dilin kazanımı konusunda yapılan bilimsel çalışmalarda; ilk yaşların özellikle de okulöncesi yıllarının kritik dönem olduğu üzerinde durulmaktadır. Bu dönemde; dilin çocuğun öğrenmesinde önemli bir etken olduğu, bu yaşlardaki kazanımların daha sonraki öğrenmeleri büyük ölçüde etkilediği sonucu okul öncesi eğitim programında vurgulanmaktadır. $\mathrm{Bu}$ nedenle okul öncesi yıllarda dil gelişimine önem verilmesi, dil gelişimini destekleyici öğretme-öğrenme ortamlarının, uyarıcı zengin çevrenin hazırlanması gereklidir. Ayrıca Türkçe dil etkinliklerinin yeteri kadar ve uygun şekilde uygulanması gereklidir (Damar, 2009). Çocuk oyunlarla, etkinliklerle veya gezilerle okuma yazmanın hayatın her noktasındaki önemini anlayacak ve okuma yazma öğrenmeye isteği artacaktır. İlkokul 1. sınıfa istekli başlayan öğrenci; okuma yazma sürecinde yer alan tüm etkinliklere katılacak ve etkin bir öğrenme süreci geçirecektir.

Okul öncesi programının sarmal bir yapıda olması nedeniyle, hedeflenen davranışlara ulaşılana kadar kazanımlar çeşitli etkinliklerle tekrar tekrar işlenmektedir. Tüm bu kazanımların öğrencide geliştirilmesi sonrasında olması gereken davranışlardan bazıları şöyle sıralanabilir; Sesin kaynağının ne olduğunu söyler. Sesler arasındaki benzerlik ve farklılıkları söyler. Verilen sese benzer sesler çıkarır. Konuşurken/şarkı söylerken nefesini doğru kullanır. Konuşurken/şarkı söylerken sesinin tonunu, hızını ve şiddetini ayarlar. Düz cümle, olumsuz cümle, soru cümlesi ve birleşik cümle kurar. Cümlelerinde öğeleri doğru kullanır. Sözel yönergeleri yerine getirir. Dinlediklerini/izlediklerini açıklar. Dinledikleri/izledikleri hakkında yorum yapar. Dinledikleri/izledikleri ile ilgili sorular sorar. Dinledikleri/izledikleri ile ilgili sorulara cevap verir. Dinlediklerini/izlediklerini başkalarına anlatır. Dinlediklerini/izlediklerini resim, müzik, drama, şiir, öykü gibi çeşitli yollarla sergiler. Sözcüklerin başlangıç seslerini söyler. Sözcüklerin sonunda yer alan sesleri söyler. Aynı sesle başlayan sözcükler üretir. Aynı sesle biten sözcükler üretir. Görsel materyalleri inceler. Görsel materyalleri açıklar. Görsel materyallerle ilgili sorular sorar. Görsel materyallerle ilgili sorulara cevap verir. Görsel materyalleri kullanarak olay, öykü gibi kompozisyonlar oluşturur. Çevresinde bulunan yazılı materyaller hakkında konuşur. Yetişkinden kendisine kitap okumasını ister. Okumayı taklit eder. Okumanın günlük yaşamdaki önemini açıklar. Yazılı materyallerde noktalama işaretlerini gösterir. Yazının yönünü gösterir. Duygu ve düşüncelerini bir yetişkine yazdırır. Yazının günlük yaşamdaki önemini açıklar (MEB, 2013). Çocuğun okul öncesi ortamda karşılaştı̆̆ kitap, dergi, gazete, görsel ve dilsel algıyı geliştirici resim çizme, tamamlama kitapları, tahmin edilebilir okuma kitapları gibi basılı araç gereçlerin yanı sıra ailede veya anaokulunda katıldığı dinleme, çizme, boyama etkinliklerinin tamamı, okul öncesinde "okuma-yazma deneyimleri" kabul edilmektedir (Çelenk, 2008). Okul öncesi eğitim çocuklara; çeşitli etkinliklerle okumayazma deneyimlerini geliştirme imkânı tanımaktadır. Bütün bu davranışlara sahip öğrencilerde, okul öncesi eğitim amacına ulaşmış kabul edilmektedir. 
Ana dili Türkçe olmayan çocukların okul öncesi eğitim alması 1. Sınıfta ilk okuma ve yazma sürecinde yaşayacakları olası sorunları büyük ölçüde azaltacaktır (Susar Kırmızı, Özcan ve Şencan, 2016). Ana dili Türkçe olmayan çocukların ve bu çocuklara eğitim veren öğretmenlerin 1. sınıfta ilk okuma yazma öğretimi sürecinde yaşadığı sorunları tespit etmek bu sorunlara çözüm üretilmesi açısından etkili olabilir. Tüm bunlara bağlı olarak araştırmanın amac1 öğretmen görüşlerine göre anadili Türkçe olmayan ve okul öncesi eğitim almamış öğrencilerin ilk okuma yazma öğrenme sürecinde yaşadığı sorunları bazı değişkenlere göre değerlendirmektir. Bu amaca bağl olarak şu alt problemler geliştirilmiştir:

1. Öğretmen görüşlerine göre okul öncesi eğitim almış ve almamış, ana dili Türkçe olmayan 1. sınıf öğrencilerinin "hazır bulunuşluk düzeyleri” nasıldır?

2. Öğretmen görüşlerine göre okul öncesi eğitim almış ve almamış, ana dili Türkçe olmayan 1. sınıf öğrencilerinin "görsel okuma becerileri" nasıldır?

3. Öğretmen görüşlerine göre okul öncesi eğitim almış ve almamış, ana dili Türkçe olmayan 1. sınıf öğrencilerinin "yazma becerileri” nasıldır?

4. Türkçenin az konuşulduğu bölgelerde okul öncesi eğitim almış öğrencilerin ilk okuma yazma öğrenme başarılarına ilişkin öğretmen algıları "sınıf mevcudu ve görev yeri”" değişkenlerine göre anlamlı bir farklılık göstermekte midir?

Öğrenci sayısı sınıf yönetimini olumlu ya da olumsuz yönde etkileyebilmektedir. Özellikle kalabalık sınıflarda öğrencilere zaman ayırmak zorlaşabilmektedir. Diğer taraftan okulun bulunduğu yer çocukların özelliğini belirlemede özellikle firsat eşitliğinin yakalanmasında önemli bir unsur olarak ortaya çıkmaktadır (Güven ve Karslı, 2014). Bu nedenle "sınıf mevcudu" ve "görev yeri" değişkenlerinin değerlendirilmesi bu çalaışmada önemli bir durum olarak görülmüştür.

\section{Yöntem}

Bu çalışmada nitel ve nicel araştırma bir arada kullanıldığ için karma yönteme başvurulmuştur (Creswell \& Plano Clark, 2007, akt: Fırat, Kabakçı Yurdakul \& Ersoy, 2014; Yıldırım ve Şimşek, 2016). Araştırmanın gerçekleştirilmesinde karma yöntemlerden de "gömülü desen" tercih edilmiştir (Creswell \& Plano Clark, 2011 akt: Fırat, Kabakçı Yurdakul \& Ersoy, 2014; Yıldırım ve Şimşek, 2013). Araştırma sürecinde gömülü desene uygun bir şekilde nicel ve nitel veriler aynı anda elde edilmiştir. Ancak nitel verilerin değerlendirilmesi daha fazla ön planda tutulmuştur.

Çalışmanın nicel boyutunun gerçekleştirilmesi için "tarama (survey) araştırması" tercih edilmiştir (Baştürk, 2010; Büyüköztürk, Kılıç Çakmak, Akgün, Karadeniz ve Demirel, 2012). Anadili Türkçe olmayan okul öncesi eğitim almış öğrencilerin ilk okuma yazma sürecindeki genel durumlarını tespit etmek için öğretmen görüşlerine başvurulmuştur. Öğretmen görüşlerinin tespit edilmesi amacıyla araştırmacılar tarafından "Ana Dili Türkçe Olmayan Öğrencilerde Okul Öncesi Eğitimin Öğrencilerin İlk Okuma Yazma Öğrenme Sürecine Etkisine İlişkin Öğretmenlerin Eğilimleri Ölçeği (ADİLKÖ)" geliştirilmiştir. Ölçek anadili Türkçe olmayan 1. sınıf öğrencilerinin ilk okuma yazma becerilerine ilişkin öğretmen eğilimleri için özel olarak düzenlenmiştir. Geliştirilen bu ölçek öğretmenlere internet üzerinden uygulanmıştır. Diğer taraftan araştırmanın nicel boyutu için de açık uçlu soru anketi kullanılmıştır. Çalışma 
kapsamında anadili Türkçe olmayan okul öncesi eğitim almış ve almamış olan öğrencilerin ilk okuma yazma sürecinde yaşadıkları sorunları karşılaştırmak amacıyla araştırmacılar tarafından açık uçlu soru anketi geliştirilmiştir. Geliştirilen açık uçlu anket, nicel boyutta kullanılan ADİLKÖ ile eş zamanlı bir şekilde internet üzerinden katılımcılara uygulanmıştır.

\section{Çalıșma Grubu}

$\mathrm{Bu}$ araştırma MEB'de görev yapan öğrenmelerin ulaşabildiği erişim ağı aracıllı̆̆ ile gerçekleştirilmiştir. Açık uçlu soru anketi ve ADÍLKÖ erişim ağı üzerinden öğretmenlere sunulmuş ve "Türkiye'nin Doğu ve Güney Doğu Bölgelerinde görev yapmakta olan 1. sınıf öğretmenlerinin yanıtlaması” talep edilmiştir. ADİLKÖ’yü yanıtlayan öğretmenlerin bir kısmı açık uçlu soru anketine de yanıt vermiştir. ADİLKÖ 176 öğretmen (kadın=79; erkek=97) tarafından doldurulurken yine aynı grup içerisinden 35 öğretmen de (kadın=21, erkek=14) açık uçlu soru anketini yanıtlamıştır. Araştırmaya katılan öğretmenlere, kişisel bilgiler formunda, eğitim dönemi başında Türkçeyi hiç bilmeyen ya da az bilen kaç öğrencisi olduğu da sorulmuştur. Elde edilen sayılar Tablo 1'de sunulmaktadır.

Tablo 1. Eğitim Dönemi Başında Türkçe'yi Hiç Bilmeyen ya da Az Bilen Öğrencilere İlişkin Sayısal Veriler

\begin{tabular}{|c|c|c|}
\hline $\begin{array}{c}\text { Öğrenci Sayıları (Türkçe’yi bilmeyen } \\
\text { ya da az bilen öğrenci sayısı) }\end{array}$ & $\begin{array}{l}\text { Öğretmen Sayıları } \\
\text { (f) }\end{array}$ & $\begin{array}{c}\text { Öğretmenlere İlişkin } \\
\text { Yüzdeler (\%) }\end{array}$ \\
\hline Türkçe bilmeyen öğrencim yok & 97 & 55,1 \\
\hline $\begin{array}{l}3 \text { Öğrenci } \quad \text { (Türkçe'yi bilmeyen } \\
\text { öğrencim var) }\end{array}$ & 3 & 1,7 \\
\hline 1 Öğrenci (Türkçe’yi az bilen öğrenci) & 14 & 8,0 \\
\hline 2 Öğrenci (Türkçe’yi az bilen öğrenci) & 11 & 6,3 \\
\hline 3 Öğrenci (Türkçe’yi az bilen öğrenci) & 8 & 4,5 \\
\hline 4 Öğrenci (Türkçe’yi az bilen öğrenci) & 4 & 2,3 \\
\hline 5 Öğrenci (Türkçe’yi az bilen öğrenci) & 8 & 4,5 \\
\hline 6 Öğrenci (Türkçe’yi az bilen öğrenci) & 4 & 2,3 \\
\hline 7 Öğrenci (Türkçe’yi az bilen öğrenci) & 3 & 1,7 \\
\hline 8 Öğrenci (Türkçe’yi az bilen öğrenci) & 2 & 1,1 \\
\hline 9 Öğrenci (Türkçe’yi az bilen öğrenci) & 2 & 1,1 \\
\hline 10 Öğrenci (Türkçe’yi az bilen öğrenci) & 2 & 1,1 \\
\hline 12 Öğrenci (Türkçe’yi az bilen öğrenci) & 2 & 1,1 \\
\hline 14 Öğrenci (Türkçe’yi az bilen öğrenci) & 3 & 1,7 \\
\hline 15 Öğrenci (Türkçe’yi az bilen öğrenci) & 2 & 1,1 \\
\hline 18 Öğrenci (Türkçe’yi az bilen öğrenci) & 1 & ,6 \\
\hline 19 Öğrenci (Türkçe’yi az bilen öğrenci) & 1 & ,6 \\
\hline 20 Öğrenci (Türkçe’yi az bilen öğrenci) & 4 & 2,3 \\
\hline 21 Öğrenci (Türkçe’yi az bilen öğrenci) & 1 & 6 \\
\hline
\end{tabular}




\begin{tabular}{lll}
\hline 23 Öğrenci (Türkçe’yi az bilen öğrenci) & 1 &, 6 \\
\hline 29 Öğrenci (Türkçe’yi az bilen öğrenci) & 1 &, 6 \\
\hline 30 Öğrenci (Türkçe'yi az bilen öğrenci) & 1 &, 6 \\
\hline 40 Öğrenci (Türkçe'yi az bilen öğrenci) & 1 &, 6 \\
\hline Toplam & 176 & 100 \\
\hline
\end{tabular}

Tablo 1'de de görüldüğü gibi araştırmaya katılan 97 öğretmen (\%55) eğitim döneminin başında Türkçe bilmeyen öğrencisinin olmadığını ifade etmiştir. Diğer taraftan 3 öğretmen (\%1,7) 3 öğrencisinin Türkçe'yi hiç bilmediğini belirtmiştir. 14 öğretmen (\%8) 1 öğrencisinin, 11 öğretmen $(\% 6,3) 2$ öğrencisinin, 8 öğretmen de $(\% 4,5) 3$ öğrencisinin Türkçe az bilen durumda olduğunu dile getirmiştir.

\section{Veri toplama Araçları}

$\mathrm{Bu}$ araştırmada, anadili Türkçe olmayan okul öncesi eğitim almış ve almamış olan öğrencilerin ilk okuma yazma sürecinde yaşadıkları sorunları karşılaştırmalı bir şekilde tespit etmek için araştırmacılar tarafından geliştirilmiş olan "açık uçlu soru anketi” ve "Ana Dili Türkçe Olmayan Öğrencilerde Okul Öncesi Eğitimin İlk Okuma Yazma Öğrenme Sürecine Etkisine İlişkin Öğretmenlerin Eğilimleri Ölçeği (ADİLKÖ)” ölçeği kullanılmıştır.

\section{Açık uçlu soru anketi}

Anket hazırlanırken öncelikle alan yazın taraması yapılmış ankete ilişkin sorular oluşturulmuştur. Hazırlanan açık uçlu sorular alanında uzman 4 öğretim üyesi ve 4 sınıf öğretmeninin görüşüne sunulmuştur. Uzman görüşü sonrası ankette bazı sorular çıkarılmış bazıları ise düzeltilmiştir. Üzerinde yapılan düzenlemelerden sonra kişisel bilgiler formu da eklenerek ankete son hali verilmiştir. Anadili Türkçe olmayan öğrencilere eğitim veren 1. sınıf öğretmenlerine yönelik olarak hazırlanan anket 3 açık uçlu soru ve kişisel bilgiler formundan oluşmaktadır. Ortaya çıkan kodların tutarlılığını tespit etmek için her bir soruya Miles ve Huberman'ın (1994) "Güvenirlik=Görüş Birliği/Görüş Ayrılı̆̆ı+Görüş Birliği x 100" formülü uygulanmıştır. Araştırma kapsamında elde edilen güvenirlik değerleri şu şekilde sıralanabilir: 1. soru için 80 ; 2. soru için 85,$71 ; 3$. soru için 80 'dir.

2. Ana dili Türkçe olmayan öğrencilerde okul öncesi eğitimin ilk okuma yazma öğrenme sürecine etkisine ilişkin ögretmenlerin eğilimleri ölçeği (ADILKÖ)

Ana dili Türkçe olmayan bölgelerde görev yapan ilkokul öğretmenlerinin okul öncesi eğitim almış ve almamış olan öğrencilerin okuma yazma sürecini değerlendirmesine yönelik olan ölçeğin geliştirilmesi için öncelikle ilgili alan yazın taranmıştır ve Türkiye'nin Doğu ve Güneydoğu bölgelerinde görev yapmış olan ilkokul öğretmenlerine konuya ilişkin açık uçlu sorular yöneltilmiştir. Elde edilen verilerden yola çıkarak madde havuzu oluşturulmuştur. Ortaya çıkan maddelerin kapsam geçerliliğini sağlamak için alanında uzman 4 öğretim elemanı ve 5 sınıf öğretmeninden olmak üzere 9 ayrı uzmandan görüş alınmıştır. Ölçekteki maddeler anadili Türkçe olmayan bölgelerde okul öncesi eğitim alan ve almayan öğrencilerin ilk okuma yazma eğitimi sürecindeki durumunu karşılaştırmalı bir şekilde ifade etmeye yönelik olduğundan uzman görüşleri doğrultusunda olumsuz madde kullanımına yer verilmemiştir. Uzman görüşleri doğrultusunda taslak ölçek üzerinde yapılan değişikliklerden sonra 47 
maddeden oluşan aday ölçek elde edilmiştir. Beşli Likert tipine uygun olarak hazırlanan ölçek maddeleri "tamamen katıllyorum=5", "katıliyorum=4", "kismen katllyorum =3", "katılmıyorum =2", "hiç katılmıyorum =1" şeklinde derecelendirilmiştir. Oluşturulan taslak ölçeğin güvenirlik çalışmaları için Denizli il merkezindeki alt, orta ve üst sosyo-ekonomik düzeydeki 12 ayrı ilkokulda görev yapan, daha önce Doğu ve Güneydoğu bölgelerinde ses temelli cümle yöntemi ile ilk okuma yazma eğitimi vermiş 246 öğretmene (erkek: 114, kadın 132) ulaşılmıştır. Ölçeğinin yapı geçerliliğini belirlemek için varimax döndürme, temel bileşenler çözümlemesi kullanılarak Açıklayıcı Faktör çözümlemesi (AFA) uygulanmıştır (Büyüköztürk, 2012; Ellez, 2014). Ölçeğin ön uygulaması sonucu elde edilen verilerin faktör çözümlemesi yeterliliğini test etmek için yapılan Kaiser-Meyer-Olkin (KMO) testi sonucunda değerin 0.94 olduğu tespit edilmiştir. Büyüköztürk'e (2012) göre bu değerin 0.70'den büyük olması nedeniyle bu veriler üzerinden faktör çözümlemesi yapılabileceği sonucuna varılmıştır. İkinci olarak elde edilen verilerin Bartlett küresellik testi (Bartlett'in Sphericity) sonucuna bakılmıştır $\left(\chi^{2}=11303,914 ;\right.$ p.=.000). Elde edilen bulgular anlamlı farklılık gösterdiği için faktör çözümlemesi yapmaya uygun olduğu belirlenmiştir. Yapılan faktör çözümlemesi sonrasında maddelerin faktör yük değerinde belirleyicilik sınırı 0.65 olarak belirlenmiştir. Bu nedenle faktör yük değeri 0.65 'in altında olan altında olan 8 madde ölçekten çıkarılmıştır. Yapılan çözümlemeler sonucunda ölçeğin 39 maddeden oluşan tek boyutlu bir ölçek olduğu tespit edilmiştir. ADİLKÖ'nün en düşük faktör yük değeri 0,66 ; en yüksek faktör yük değeri ise 0,80'dir. Cronbach's Alpha güvenirlik katsayıs1 ise 0,98'dir. Ölçek uygulanırken her bir katılımcının ölçekten alabileceği ağırlıklı ham puan en az 39, en çok ise 195'tir. ADİLKÖ'den elde edilen toplam puanın yüksek olması, öğretmenlerin anadili Türkçe olmayan bölgelerde okul öncesi eğitim alan öğrencilere yönelik olarak eğilimlerinin olumlu olduğunu; düşük olması da anadili Türkçe olmayan bölgelerde okul öncesi eğitim alan öğrencilere yönelik olarak eğilimlerinin olumsuz olduğunu ortaya koymaktadır (Bkz. EK A). ADİLKÖ'nün geliştirilmesi tamamlandıktan sonra 176 öğretmenle yapılan çalışmadan elde edilen verilerden ortaya çıkan Cronbach's Alpha güvenirlik katsayısı ise 0,97 'dir.

\section{Verilerin Çözümlenmesi}

Açık uçlu soru anketinin internet üzerinden uygulanmasından sonra öğretmenlerden elde edilen nitel veri seti büyük bir duyarlılıkla araştırmacılar tarafindan detaylı bir şekilde okunmuş ve bilgisayar ortamına aktarılmıştır. Öğretmenlerin konuya ilişkin görüş ve düşüncelerini belirlemek için verilere içerik çözümlemesi uygulanmıştır. Veriler okunurken kodları belirlenmiş, belirlenen kodlardan ilişkili olanlar bir araya getirilerek temalar oluşturulmuştur. Belirlenen kodlar, alt kodlar ve temalar Tablo 2'de sunulmuştur.

Tablo 2'de de görüldüğü gibi nitel verilere uygulanan içerik çözümlemesi sonucunda 3 tema ve 7 kod belirlenmiştir. Kodların kendi içindeki farkl1lıklardan hareketle 2 alt kod ortaya çıkarılmıştır. En çok görüş bildirilen kod ise "Okul öncesi eğitim almış grubun görselleri yorumlaması" kodudur. Bu koda yönelik olarak $26(\% 74,28)$ öğretmen düşüncelerini dile getirmiştir. En az görüş bildirilenler ise "motivasyon" alt kodudur. Bu alt koda yönelik olarak 4 katılımcıdan $(\% 11,42)$ görüş gelmiştir. 
Tablo 2. Araştırma Verilerinden Elde Edilen Temalar, Kodlar ve Alt Kodlar

\begin{tabular}{|c|c|c|c|c|}
\hline Temalar & Kodlar & $\begin{array}{l}\text { Kodlara İlişkin } \\
\text { Belirlenen } \\
\text { Görüş Sayısı ve } \\
\text { Yüzdesi }\end{array}$ & Alt Kodlar & $\begin{array}{c}\text { Alt Kodların } \\
\text { Tekrarlanma } \\
\text { Sıklığ } 1\end{array}$ \\
\hline \multirow{2}{*}{$\begin{array}{l}\text { 1. Tema: Uyum } \\
\text { aşaması }\end{array}$} & 1. Hazır bulunuşluk & $15(\% 42,85)$ & - & - \\
\hline & 2. Motivasyon & $4(\% 11,42)$ & - & - \\
\hline \multirow{3}{*}{$\begin{array}{l}\text { 2. Tema: Görsel } \\
\text { Okuma }\end{array}$} & $\begin{array}{l}\text { 1. Okul öncesi eğitim almış grubun } \\
\text { görselleri yorumlaması }\end{array}$ & $26(\% 74,28)$ & - & - \\
\hline & $\begin{array}{l}\text { 2. Okul öncesi eğitim almamış grubun } \\
\text { görselleri yorumlaması }\end{array}$ & $7(\% 20)$ & - & - \\
\hline & $\begin{array}{l}\text { 3. Görselleri yorumlamada farklılık } \\
\text { görülmeme durumu }\end{array}$ & $5(\% 14,28)$ & - & - \\
\hline \multirow{3}{*}{$\begin{array}{l}\text { 3.Tema: } \\
\text { becerisi }\end{array}$} & 1.İyi yazı yazma becerisi & \multirow[t]{2}{*}{$23(\% 65,71)$} & $\begin{array}{l}1 . \quad \text { Küçük } \\
\text { kasların } \\
\text { gelişmiş olması }\end{array}$ & $12(\% 34,28)$ \\
\hline & & & 2.Yazma isteği & $8(\% 22,85)$ \\
\hline & 2.Yazma yaşanan zorluklar & $6(\% 17,14)$ & - & - \\
\hline
\end{tabular}

Tema ve kodlar sunulurken de öğretmen görüşlerinden alıntılara yer verilmiştir. Alıntılar sunulurken öğretmenlerin kişisel özelliklerine ilişkin bir takım bilgiler kısaltmalar aracılığ 1 ile verilmiştir. Öğretmenlerin ifadelerinden yapılan alıntılarda kullanılan kısaltmalar, sıra no (1, 2, 3 vb.); bayan (B), erkek (E); öğretmenin kıdemi (4 y1l, 5 y1l, vb.), Türkçe bilmeyen ya da az bilen öğrenci sayısı (0 öğrenci, 1 öğrenci vb.)1. sınıf, 2. sınıf, 3. sınıf, 4. sınıf) Örneğin: (22, B, 5 yıl, 0 öğrenci) 4. sınıf) 22: 22. sıradaki öğretmen; B: Bayan; 5 yıl: 5 yıllık öğretmen; 0 Öğrenci: Türkçe bilmeyen ya da az bilen öğrenci sayısıdır.

\section{Bulgular}

Araştırmanın bu bölümünde belirlenen alt problemleri yanıtlamak için elde edilen veriler çözümlenmiş ve ortaya çıkan bulgular sunulmuştur. Bulguları desteklemek amacıyla yorumlara yer verilmiştir.

\section{Birinci Alt Probleme İlişkin Bulgular ve Yorum}

Araştırmanın birinci alt problemine yanıt vermek amacıyla "uyum aşaması" teması ortaya çıkarılmıştır. Bu temanın ortaya çıkmasında hazır bulunuşluk ve motivasyon kodları etkili olmuştur. Belirlenen kodlara ilişkin alıntılar şunlardır:

Hazır Bulunuşluk Kodu: “(...) Okul öncesi eğitim almış bir öğrenci ile iletişim kurmak daha kolay. [2, K, 4yıl, 10 öğrenci]” “(...)Okul öncesi eğitim almış çocuklarda oturma, arkadaşlık kurma, ders araç gereçlerini doğru kullanma, dersliğe girip çıkma ve özellikle Türkçe konuşma konularında da hiçbir zorluk yaşanmıyor. [4, E, 24 yıl, 10 öğrenci]” "(...)Okul öncesi eğitim almış öğrenciler; iyi bir çalışma yapılmışsa el bilekleri ve becerileri gelişmiş; 
anlama becerileri iyi, okul kurallarına uyan bireyler olarak eğitim-öğretime hazır durumdadırlar. Kalem tutma, boyama, okul eşyalarını kullanma becerileri gelişmiştir. Eğitim almamış öğrencilerde bunlar görülmez. [11, E, 35 y1l, 1 öğrenci]” “(...)Okul öncesi eğitim almış öğrencilerde el ve bilek kasları daha iyi gelişmiş oluyor. Boyamaları daha iyi yapabilen, yönergeleri takip edebilen bir durumu içinde oluyorlar. Okul öncesi eğitim almamış öğrenciler sınıfa uyumda zorlanıyor. Kalem tutmada, yönergeleri takip etmede boyama yapmada güçlük çekiyor. [ 12, K, 35 yıl, 1 öğrenci]"

Araştırmaya katılan 35 öğretmenden 15’i $(\% 42,85)$ okul öncesi eğitimin hazır bulunuşluk düzeyine olumlu etkileri olduğu yönünde görüş bildirmiştir. Okul öncesi eğitim çocukta okul kültürünün gelişmesini sağlamanın yanı sıra kendini ifade etme, yönergeleri anlama ve uygulayabilme becerilerini kazanmalarını da sağlar. Özellikle Ana dili Türkçe olmayan bölgelerde, okuma yazma eğitiminin temelini oluşturan dili tanıma, anlama ve yorumlama becerilerini okul öncesi eğitimle kazanabilmektedirler. Araştırmaya katılan öğretmenler yaptıkları açıklamalarda bu duruma vurgu yapmıştır.

Motivasyon Kodu: “(...) Okul öncesi eğitim almış öğrencilerin hazır bulunuşluk düzeyleri daha yüksektir ve bu öğrencilerle işlenen dersler daha verimli ve kaliteli olmaktadır. Okul öncesi eğitimi almamış öğrenciler başarısız olduklarında motivasyonları düşüyor, öğrenme güçlüğü çekmeye başliyorlar. Okul öncesi eğitimi alan öğrenciler birinci sınıfta daha çabuk sosyalleşiyor ve kavrama yetenekleri daha yüksek oluyor. [1, K, 9 yıl, 0 öğrenci]” “(...) Okul öncesi eğitim almış öğrencilerin el kol kas koordinasyonunda gelişme olur. Böylece okula olan motivasyonları da ve derslere karşı hazır bulunuşluk düzeyleri artar. [35, K, 15 yıl, 1 öğrenci]" “(...)Öğrencilerin ilkokula hazırlık yapabilmesi için anasınıfının çok önemli olduğunu düşünen öğretmenlerdenim. Öğretim bölümünden ziyade çocuğun bir sınıf düzeninde yapması ya da yapmaması gerekenleri, belirli bir saati öğretmenle geçirme alışkanlığını ve sosyalleşme gibi önemli bir olguyu anasınıfinda kazanmaya başladıklarını düşünüyorum. Ayrıca 1. sınıf öğretmeni ve velileri olarak anasınıfına giden öğrenci ile gitmeyen öğrenci arasında oluşan uçurumu kapatmakta çok zorlanıyoruz. En basitinden anasınıfına gitmeyen bazı öğrencileri sınıfta tutmakta bile zorlanabiliyoruz. Anasınıfina giden öğrenciler yapılan etkinlikleri basit bulup aynı şeyleri yapmaktan sıkılıyor, gitmeyen öğrenciler ise yeni girdikleri ortamda diğerlerinin kolayca yaptıkları etkinlikleri yapamadıkları için çok büyük kaygılar yaşayıp okula ve derslere karşı isteksizlik oluşturabiliyorlar. El becerisi ve zekası iyi düzeyde olanlar bu dönemi atlatabilseler de 2. ve 3. sinıftaki derslerde bile bu eksikliği hissedebiliyorlar. [16, K, 13 y1l, 0 öğrenci]"

Alıntılar incelendiğinde araştırmaya katılan 35 öğretmenden 4'ünün $(11,42)$ okul öncesi eğitimin öğrencilerin motivasyonlarına etkileri ile ilgili görüş bildirdiği tespit edilmiştir. Öğretmenlerin görüşlerine göre Ana dili Türkçe olmayan bölgelerde okul öncesi eğitimde oyun aracılığıyla öğrencilerin dil becerileri geliştirilmektedir. Bu sayede Türkçeyi anlama ve yorumlama becerilerini kazanan öğrencinin motivasyonu da artmaktadır.

\section{İkinci Alt Probleme İlişkin Bulgular ve Yorum}

Araştırmanın ikinci alt problemine yanıt vermek için "görsel okuma" teması ortaya çıkarılmıştır. "Görsel okuma" teması kapsamında "okul öncesi eğitim almış grubun görselleri yorumlaması, okul öncesi eğitim almamış grubun görselleri yorumlaması ve görselleri yorumlamada farklılık 
görülmeme durumu" kodları belirlenmiştir. Belirlenen kodlara ilişkin elde edilen alıntılardan bazıları şunlardır.

Okul Öncesi Eğitim Almış Grubun Görselleri Yorumlaması Kodu: “(...) Okul öncesi eğitim alan öğrencilerin görsel okuma düzeyleri diğerlerine oranla daha yüksektir. Yorumlama becerileri daha fazladır. [1, K, 9 yıl, 0 öğrenci]” “(...) Okul öncesi eğitim almış öğrencilerin almamış öğrencilere göre konuşma, izleme ve yorumlama becerileri daha gelişmiş olduğundan görsel okuma düzeyleri de daha yüksek ve başarılıdır. [21, E, 19 y1l, 0 öğrenci]” “(...) Okul öncesi eğitimi alan öğrenci anasınıfında birçok görsel materyalle çalıştığından bu eğitimi almayan öğrenciden daha ileri seviyede bir görsel okuma düzeyine sahiptir. [22, Bay, 5 yıl, Merkez İlçe]” “(...) Okul öncesi eğitim almış çocuklar görsel okumalarda duygu ve düşüncelerini, gördüklerini rahatlıkla anlaşılabilir bir şekilde ifade edebiliyorlar. [4, E, 24 y1l, 10 öğrenci]” “(...) Okul öncesi eğitim almış öğrencilerin görsel okuma düzeyleri gelişmiştir. Görselle ilgili yorum yapabilirler. [13, E, 24 y1l, 1 öğrenci]” “(...) Ana dili Türkçe olmayan ve okul öncesi eğitimi alan öğrencilerle yapılan görsel yorumlama çalışmaları aynı zamanda dil becerilerini de geliştirmektedir. Türkçeyi daha iyi kullanıp gördügünü daha iyi ifade ediyor. [20, E, 12 yı1, 3 öğrenci]"

Okul Öncesi Ĕ̈itim Almamış Grubun Görselleri Yorumlaması: “(...)Okul öncesi eğitim almış öğrenci daha başarılı çünkü anasınıfında bu tür etkinliklerde yer almış ama almayan öğrenci zaten Türkçeyi bilmediği için görselleri ifade etmede başarılı olamıyor. [16, K, 13 yıl, 0 öğrenci]” “(...)Okul öncesi eğitim almamış öğrenciler şekil, resim, harf gibi görsellere yabanc1lık çekiyor. Kendini ifade etmekte zorlanıyor. Okul öncesi eğitimi alanlar ise bu sürece alışkın bir biçimde uyum sağlıyor. [18, E, 2 yıl, 6 öğrenci]” “(...)Okul öncesi eğitim almamış öğrenciler görsel okumada kendilerini ifade bakımından sıkıntı yaşayabilmektedirler. Kelime hazineleri diğer arkadaşlarına göre daha zayıf olan bu öğrenciler kısa ve basit cümlelerle yalın bir anlatım gerçekleştirebilmektedirler. [31, K, 9 yıl, 3 öğrenci]” “(...) Okul öncesi eğitim almamış öğrenciler Türkçeyi iyi kullanamadıklarından görsel okuma düzeyleri çok düşük, okul öncesi almış öğrencilerin ise görsel okuma düzeyleri daha mükemmel. [14, E, 27 yı1, 0 öğrenci]"

Görselleri Yorumlamada Farklılı Görülmeme Durumu: “(...)Görselleri inceleme ve okumada çok büyük farkl1lık yok ancak görselleri anlatma aşamasında problem oluyor. $[9, \mathrm{~K}$, 12 y1l, 3 öğrenci]” "(...)Türkçe konuşulmayan bölgelerde de çalıştığım için öğrenci arasında farklılıklar çok fazla olmadı çünkü evde de Türkçe konuşulmadığı için ilerlemeler kaydedilmedi. Öğrencilerin birkaç tanesi farkl1lıklar gösterirdi. $\mathrm{Bu}$ da yeterli değildi. $\mathrm{O}$ bölgelerde sınıfta hepsinin öğrenmesi yeterli idi. [17, K, 35 yıl, 0 öğrenci]” “(...) Görsel okuma düzeylerinde herhangi bir faklılık yoktur. [19, K, 9 yıl, 5 öğrenci]"

Araştırmaya katılan 35 öğretmenden 26'sı(\%74,28) okul öncesi eğitim almış grubun görselleri yorumlamasına yönelik olarak olumlu görüşler bildirirken 7'si $(\% 20)$ ise okul öncesi eğitim almamış grubun görselleri yorumlamasına ilişkin olumlu olmayan görüşler bildirmişlerdir. Aynı zamanda 5 (\%14,28) öğretmen okul öncesi eğitim almış grup ile okul öncesi eğitim alamamış grupların arasında görsel okuma ile ilgili olarak herhangi bir fark olmadığ 1 yönünde görüş ortaya koymuştur. Okul öncesi eğitimde görsellere geniş yer verilmesi nedeniyle çocuklar görselleri daha iyi yorumlayabilmektedir. Öğrenciler görselleri yorumlarken de Türkçe'yi kullanmakta ve dil becerileri de bu çalışmalardan olumlu yönde etkilenmektedir. 


\section{Üçüncü Alt Probleme İliş̧kin Bulgular ve Yorum}

Araştırmanın altıncı alt problemine yanıt vermeye yönelik olarak oluşturulan "yazma becerisi" teması kapsamında iki kod yer almaktadır. Bu kodlar "iyi yazma becerisi ve yazma sürecinde yaşanan zorluklar" olarak belirlenmiştir. "İyi yazma becerisi" koduna bağlı olarak da "küçük kasların gelişmiş olması, yazma isteği" alt kodları tespit edilmiştir... Belirlenen alt kodlara ilişkin alıntılar şunlardır:

İyi yazma becerisi: “(....) Okul öncesi eğitim almış öğrencilerin kalem tutma becerileri daha önce geliştiği için yazmada zorlanmazlar. [12, B,35 y1l, 0 öğrenci]” “(....) Okul öncesi eğitimi alan öğrencinin küçük kasları gelişmiş olduğu için yazmada ileri seviyededir. [22, B, 5 yı1, 0 öğrenci]" Bu koda bağlı olarak belirlenmiş olan "küçük kasların gelişmiş olması" ve "yazma isteği”" alt kodları için de elde edilen alıntılardan bazıları aşağıdadır:

a. Küçük kasların gelişmiş olması: “(...) Okul öncesi eğitim almış öğrenciler; çizgi ve boyama çalışmaları yaptığı için el kasları iyi gelişmiştir ve bu da öğrencilerin yazı yazma çalışmalarında başarılı olmasını sağlar. [8, E, 10 yıl, 0 öğrenci]” “(...) Eğitim almış olanların birçoğunun kas gelişimi daha iyi olduğu için yazma performansları da iyidir. Diğer çocuklar çabuk yorulmaktadır. [9, B,12 y1l, 3 öğrenci]” “(...)Okul öncesinde parmak kasları ince davranışları kazandığından etkisi olumlu yöndedir. [20, B, 12 yıl, 3 öğrenci]” “(...) Okul öncesi eğitim almış öğrencilerin el, parmak kasları daha iyi geliştiğinden yazma becerileri bu eğitimi almayan 1. sınıf öğrencilerine göre daha iyidir. [21, E,19 yıl, 0 öğrenci]",

b. Yazma isteği: “(...) Okul öncesi eğitim almış öğrenciler yazmaya daha isteklidir. [25, B,11 yıl, 2 öğrenci]” “(...) Okul öncesi eğitim alanların yazma istekleri daha iyidir. Çünkü yazma çalışmalarındaki sözcüklerle daha önceden tanışmış oluyorlar. [27, B, 28 yıl, 0 öğrenci]." Araştırmaya katılan 35 öğretmenden 23'ü $(\% 65,71)$ okul öncesi eğitim almış öğrencinin iyi yazma becerisine sahip olduğunu belirtmiştir. 12 öğretmen $(\% 34,28)$ okul öncesi eğitim almış grubun küçük kaslarının gelişmiş olduğunu bu sayede 1.sınıfa başlayan öğrencilerin kalem tutmasını öğrenmiş olarak okula başladıklarını belirtirken, 8 öğretmen ise okul öncesi eğitim almış öğrencilerin yazma isteklerinin daha güçlü olduklarını belirtmiştir. Türkçe'nin az konuşulduğu bölgelerde okul öncesi eğitim almış öğrencilerin kalem tutmayı öğrenmiş olarak okula başlaması öğrencinin özgüven kazanmasını sağlar.

Bazı öğretmenler ise belirlenen alt kodların dışında farklı konulara değinmiştir: “(...) Okul öncesi eğitim almış öğrenci sınıf içi etkinliklerde daha güvenli ve daha istekli olduğundan bu durum yazma becerilerini de olumlu etkilemektedir. [32, B,10 y1l,2 öğrenci]” Bu alıntıda genel olarak okul öncesi eğitimin öğrencide oluşturduğu özgüven duygusundan ve bunun yazma sürecine yansımasından söz edilmektedir. Araştırmaya katılan öğretmen okul öncesi eğitimin yazma başarısına olan etkisine vurgu yapmaktadır. Başka bir alıntıda ise öğretmenlerden birisi okul öncesi eğitim alan öğrencilerin ilk başta yazma performanslarının iyi olacağını fakat okul öncesi eğitim almamış öğrencilerin kısa bir sürede aynı performansa sahip olabileceklerini belirtmiş: “(...)Eğitim almış öğrenciler genellikle yazma çalışmalarında başarılı olurken, eğitim almayanlardan da aynı performansı yakalayanlar oluyor. [29, B, 29 yıl,0 öğrenci]" Alıntılardan da anlaşılacağı gibi okul öncesi eğitim almış olan öğrenci yazma eğitimine avantajlı bir şekilde başlamaktadır. 
"Yazma becerisi" temasının ikinci kodu "yazmada yaşanan zorluklar" şeklinde belirlenmiştir. Bu koda ilişkin alıntılar şunlardır:

Yazma Yaşanan Zorluklar: “(...)Okul öncesi eğitim almamış öğrencilerin Türkçeyi iyi anlama yönleri başarısız, kas gelişimleri de geri olduğu için yazma performansları düşüktür. [14, B, 27 y1l, 0 öğrenci]” “(...) Okul öncesi eğitim almış öğrenci kalem tutmada daha başarılı, çizgi çalışmalarını yapmış olarak geldiği için zorluk yaşanmıyor ama bu eğitimi almamış öğrenci için aynı şeyleri söylemek pek mümkün değildir. [16, B,13 yıl, 0 öğrenci]” “(...)Okul öncesi kurumlarına gitmeyen, kalem tutma alışkanlığı kazanmamış öğrenciler yazmada zorlanmaktadır. [23, B, 14 y1l, 0 öğrenci]” “(...) Okul öncesi eğitim almamış olanlar çabuk yorulma, yazıda özensizlik; daha ileri safhalarda kelimelerde eksik harfler yazma gibi sıkıntılar yaşayabiliyor. [31, B, 9 yıl, 0 öğrenci]” "(...) Okul öncesi eğitim almayan öğrenciler Türkçenin az konuşulmasının da etkisiyle zaten konuşmada zorluk çekiyorlar yazmada da bu durumdan etkileniyorlar. [1, B, 9 yı1, 0 öğrenci]”

Araştırmadan elde edilen bulgular incelendiğinde 6 öğretmen $(\% 17,14)$, okul öncesi eğitim almamış öğrencilerde yazma alıştırmaları sürecinde sıkıntılar yaşandığını dile getirmiştir. Öğretmenlere göre okul öncesi eğitim almayan öğrenciler Türkçe konuşma ve kendini ifade etmede de bir takım sıkıntılar yaşamaktadır. Öğrencilerin ilkokula gelmeden önce Türkçe konuşabilecekleri bir eğitim ortamında bulunmamış olmaları birinci sınıfa başladıklarında kendini ifade etmede sorun yaşamalarına neden olmaktadır. Bu durum öğretmen ve öğrenci arasında iletişim sorununun da ortaya çıkmasına neden olmakta ve yazma eğitimi sürecini de olumsuz etkilemektedir.

\section{Dördüncü Alt Probleme İlişkin Bulgular ve Yorum}

ADİLKÖ'den elde edilen puanlar "sınıf mevcudu değişkenine göre" çözümlenmiş ve t-testi uygulanmıştır. Elde edilen sonuçlar Tablo 3'te sunulmaktadır.

\section{Tablo 3. ADİLKÖ puanlarının "sınıf mevcudu değişkenine göre" t-testi sonuçları}

\begin{tabular}{lcccccc}
\hline Sinıf Mevcudu & $\mathrm{N}$ & $\overline{\mathrm{x}}$ & $\mathrm{SS}$ & $\mathrm{sd}$ & $\mathrm{t}$ & $\mathrm{p}$ \\
\hline 10-24 arası öğrenci & 68 & 167,54 & 29,34 & 174 & 0,555 & 0,631 \\
25-50 arası öğrenci & 108 & 164,89 & 31,70 & & & \\
\hline
\end{tabular}

Tablo 3 incelendiğinde anadili Türkçe olmayan bölgelerde okul öncesi eğitim alan öğrencilerin ilk okuma yazma öğrenme başarılarına ilişkin olarak öğretmen algıları sınıflarının mevcuduna göre herhangi bir farkl111k göstermemektedir $\mathrm{t}(174)=0,555 ; \mathrm{p}>0,01$. Öğrenci say1s1 10-24 olan öğretmenlerle $(\bar{x}=167,54)$ öğrenci sayıs1 $25-50$ olan öğretmenlerin $(\bar{x}=164,89)$ algıları birbirine benzerdir. Sınıftaki öğrenci sayısı öğrenme öğretme sürecinin niteliğinde önemli bir belirleyicidir. Öğrenci sayısının az olması öğretmen öğrenci ilişkisi, öğrencinin kendini sınıf içinde ifade etmesi gibi konularda olumlu bir durum olarak ortaya çıkmaktadır. Ancak yapılan çözümlemelerde sınıftaki öğrenci mevcudunun öğretmenlerin algısını etkilemediği tespit edilmiştir. Öğretmenlerinin algılarının "görev yeri değişkenine göre" anlamlı bir farkl1lık gösterip göstermediği incelenmiş ve elde edilen puanlara tek faktörlü varyans çözümlemesi (one-way anova) uygulanmıştır. Tek faktörlü varyans çözümlemesi sonuçları Tablo 4'te sunulmaktadır. 
Tablo 4. ADİLKÖ puanlarının "görev yeri değişkenine göre” ANOVA sonuçları

\begin{tabular}{|c|c|c|c|c|c|c|c|c|c|}
\hline Gruplar & $\mathrm{N}$ & $\overline{\mathrm{x}}$ & SS & $\begin{array}{l}\text { Varyansın } \\
\text { Kaynağı }\end{array}$ & $\begin{array}{l}\text { Kareler } \\
\text { Toplamı }\end{array}$ & $\mathrm{Sd}$ & $\begin{array}{l}\text { Kareler } \\
\text { Ortalamas1 }\end{array}$ & $\mathrm{F}$ & $\mathrm{p}$ \\
\hline İl merkezi & 50 & 161,70 & 38,94 & $\begin{array}{l}\text { Gruplar } \\
\text { aras1 }\end{array}$ & 2712,15 & 2 & 1356,07 & 1,44 & 0,240 \\
\hline İlçe & 69 & 164,49 & 31,53 & $\begin{array}{l}\text { Gruplar } \\
\text { İçi }\end{array}$ & 162840,72 & 173 & 941,27 & & \\
\hline Köy & 57 & 171,35 & 19,30 & Toplam & 165552,88 & 175 & & & \\
\hline Toplam & 176 & 165,92 & 30,75 & & & & & & \\
\hline
\end{tabular}

Tablo 6 incelendiğinde ana dili Türkçe olmayan bölgelerde okul öncesi eğitim alan öğrencilerin ilk okuma yazma öğrenme başarılarına ilişkin olarak öğretmen algılarının görev yeri değişkenine göre anlamlı bir farklılık olmadığı belirlenmiştir $F(2,173)=1,44, P>0,01$. Öğretmenlerin okul öncesi eğitim alan öğrencilere ilişkin algıları görev yaptıkları yerin il $(\bar{x}=161,70)$, ilçe $(\bar{x}=164,49)$ ya da köy $(\bar{x}=171,35)$ olması durumuna göre değişmediği söylenebilir. Öğretmenlerin görev yaptığı yer eğitim sürecine olumlu ya da olumsuz yönde etki edebilir. Öğretmenin köy, köy ya da il merkezinde görev yapıyor olması karşılaştıkları öğrenci profili açısından önemli olduğu göz önüne alındığında farkın anlamsız olması dikkate değer bir durumdur.

\section{Sonuç, Tartışma ve Öneriler}

Araştırmaya katılan 35 öğretmenden $15^{\prime}$ i $(\% 42,85)$ okul öncesi eğitimin ana dili Türkçe olmayan öğrencilerin hazır bulunuşluk düzeyine olumlu etkilerinin olduğunu belirtmiştir. Öğretmenlere göre okul öncesi eğitim almış öğrenciler okuma yazma eğitimi için gerekli ön bilgileri ve becerileri edinmiş bir şekilde ilkokula başlamaktadır. Bu durum onların Türkçe konuşma becerilerini desteklemekte başkaları ile iletişim kurabilme yetilerini geliştirmektedir. Okul öncesi eğitim almış öğrenciler, Türkçeyi daha iyi kullandıkları için de yönergeleri anlayabilmekte ve uygulayabilmektedir. Okuma yazma öğretiminin önemini öğrenmiş ve okuma yazma öğrenmeye isteklidir. Okul öncesi eğitimde Türkçe eğitim aldıkları için de sesleri daha iyi tanımakta ve ayırt edebilmektedir. Aslan, Aslantaş ve Aslan (2015) Şırnak’ta 18 ilkokulda, 30 birinci sınıf ögretmeni ile yaptığı araştırmada ana dili Türkçe olmayan öğrencileri ilk okuma yazma öğretiminde karşılaştıkları problemleri tespit etme çalışmıştır. Çalışmada veri toplama aracı olarak "Ana Dili Türkçe Olmayan Öğrencilere İlk Okuma-Yazma Öğretiminde Karşılaşılan Problemler Anketi” kullanılmıştır. Araştırmanın sonucuna göre öğrencilerin okul öncesi eğitim almış olmaları onların ilk okuma yazma öğretimini kolaylaştırmaktadır. Okul öncesi eğitimin ilk okuma yazma öğrenme sürecine etkisine ilişkin gerçekleştirilen diğer çalışmalara da ulaşılmıştır. Ulaşılan bu çalışmalar da okul öncesi eğitimin ilk okuma yazma eğitimi sürecine olumlu etkileri olduğu yönündedir. Elde edilen bu sonuçlar daha önce yapılan diğer araştırmalarla paralellik göstermektedir. Çelenk (2008) yaptı̆̆ 1 araştırmada ilköğretim okulları birinci sınıf öğrencilerinin ilk okuma ve yazma öğrenme hazırlık düzeylerine ilişkin benzer sonuçlara ulaşmıştır. $\mathrm{Bu}$ araştırmanın sonuçlarına göre okul öncesi eğitim almış öğrenciler ilk okuma ve yazma öğrenmek için çok önemli deneyim ve birikimlerle (duyusal hazırlık düzeyi, okuma ve yazma ön hazırlık ile) okula gelmektedirler. Araştırmada okul öncesi eğitimin öğrencilerin duyuşsal hazırlık düzeyi ile okuma yazma öğrenmeye yönelik ön hazırlıkları üzerinde önemli bir etkileri olduğu sonucuna ulaşılmıştır. Erkan ve Kırca (2010) "Okul Öncesi Eğitimin İlköğretim Birinci Sınıf Öğrencilerinin Okula Hazır Bulunuşluklarına 
Etkisinin İncelenmesi" üzerine bir çalışma yapmıştır. Bu çalışma; bünyesinde anasınıfı bulunan ilköğretim okullarının birinci sınıfına devam eden 170 çocuk üzerinde yapılmıştır. Çalışmanın verileri Metropolitan Okula Hazır Bulunuşluk Testi ve Aile Anket Formu kullanılarak toplanmıştır. Araştırma sonucunda da okul öncesi eğitim alan çocukların hazır bulunuşluk düzeylerinin, okul öncesi eğitim almayan çocuklara göre daha yüksek olduğu görülmüştür. Susar Kırmızı, Özcan ve Şencan (2016) 27 ayrı okulda, 72 öğretmenle yaptığı araştırmada Türkçenin az konuşulduğu bölgelerde ilk okuma yazma sürecinde karşılaşılan sorunlara ilişkin öğretmen görüşlerini tespit etmeyi amaçlamıştır. Verilerin elde edilmesinde araştırmacılar tarafından hazırlanan, 10 sorudan oluşan "Açık Uçlu Soru Anketi” kullanılmıştır. Araştırmanın sonuçlarına göre okul öncesi eğitim sürecinde çocuklar aldığı eğitim sayesinde daha fazla sosyal ortamlarda bulunmakta ve daha fazla konuşmaktadır. Bu durum öğrencinin daha etkili bir Türkçeye sahip olmasını sağlamaktadır.

Araştırmaya katılan 35 öğretmenden 4'ü $(\% 11,42)$ okul öncesi eğitimin ana dili Türkçe olmayan öğrencilerin motivasyonlarını arttırdığı yönünde görüş bildirmiştir. Öğretmenlerin görüşlerine göre okul öncesi eğitim almış öğrenciler ilk okuma yazma eğitimi için gerekli ön bilgilere sahip olarak okula başlamaktadır. Okul öncesi eğitim almış öğrenciler okuma yazmanın yaşamındaki yerini ve okuma yazma öğrenmenin gerekliliğini bilmektedir. Türkçe okuma ve yazmanın yaşamına katkılarına ilişkin olarak önemli bir farkındalığa sahiptir. Aynı zamanda bu çocuklar okul kaygısı da yaşamamaktadır. Okul öncesi eğitimde aldıkları Türkçe eğitim onların ilkokulda okul ortamını daha kolay tanımalarına yardımcı olmaktadır. Öğretmenlere göre bu öğrencilerin ilk okuma yazma öğrenme sürecinde özgüvenleri de yüksek olmaktadır. Elde edilen bu sonuçlar daha önce yapılan araştırmaları destekler niteliktedir. Pehlivan (2006), "Okul Öncesi Eğitim Alan ve Almayan Öğrencilerin İlk Okuma Yazmaya Geçiş Sürecinin, Öğretmen ve Öğrenci Görüşleri Doğrultusunda Değerlendirilmesi" üzerine bir çalışma yapmıştır. Bu araştırmada veriler, ilk okuma yazmayı öğretme yönteminde ses temelli cümle yöntemi uygulamasında ilk okuma yazmaya geçiş döneminde, okul öncesi eğitim alan ve almayan öğrencilerin yaşadıklarını belirlemek üzere, araştırmacı tarafından yarı yapılandırılmış olarak geliştirilen Öğretmen Görüşme Formu, Öğrenci Görüşme Formu ve araştırma kapsamına giren öğrencilerle ilgili bilgi elde etmek amacıyla hazırlanan Kişisel Bilgi Formu kullanılarak toplanmıştır. Pehlivan (2006), bu çalışmada elde ettiği veriler doğrultusunda okul öncesi eğitim almış öğrencilerin derslerde, daha dikkatli, katılımcı, yaratıcı olduklarını ve kuralları daha çabuk algıladıklarını belirtmiştir. Yangın (2007) "Okul Öncesi Eğitim Kurumlarındaki Altı Yaş Çocuklarının Yazmayı Öğrenmeye Hazır Bulunuşluk Durumları" üzerine bir çalışma yapmıştır. Çalışmanın verileri, 2003-2004 öğretim yılında, Ankara'daki okul öncesi eğitim kurumlarının altı yaş grubundaki 64 öğrenciye araştırmacı tarafından geliştirilen ölçeğin bireysel olarak uygulanması ile elde edilmiştir. Bu çalışmada elde edilen veriler doğrultusunda, okul öncesi eğitim almış çocukların el becerilerini "yeterli" düzeyde kazandıkları sonucuna ulaşmıştır.

Araştırmaya katılan 35 öğretmenden 26's1 $(\% 74,28)$ ana dili Türkçe olmayan okul öncesi eğitim almış öğrencilerin görselleri yorumlamada daha başarılı olduklarını belirtmiştir. Katılımcılardan 7'si (\%20) ise ana dili Türkçe olmayan ve okul öncesi eğitim almamış öğrencilerin görselleri yorumlamada gereken başarıyı ortaya koyamadığını dile getirmiştir. Dil becerileri yeterince gelişmemiş olan öğrenciler görselleri yorumlamada da beklenen düzeyde değildir. Öğretmen görüşlerine göre okul öncesi eğitim sürecinde öğrenciler birç̧ok görselle karşılaşmaktadır. Ayrıca bu görsellerin yorumlanması çalışmalarına yer verilmektedir. Bu 
durum öğrencilerin Türkçe konuşma becerilerinin artmasına katkı sağladığı gibi görsel okuma ve görsel sunu becerilerinin belli bir seviyeye ulaşmasına etki etmektedir. Bu öğrenciler görsellerdeki ayrıntıları yakalama, resimleri doğru sıralama, konuya ilişkin Türkçe açıklamalar yapma vb. becerilerde daha ileri düzeyde olabilmektedir. Elde edilen bu sonuçlar yapılan diğer araştırmaları da destekler niteliktedir. Aslanargun ve Tapan (2012), okul öncesi eğitim ve çocuklara etkileri üzerine yaptıkları çalışmada; okul öncesi eğitim alan çocukların gördüklerini anlatabilme, yorum yapabilme ve özetleyebilme gibi becerilerle ilgili annelerinin görüşlerini tespit etmiştir. Araştırma sonuçlarına göre anneler çocukların görselleri yorumlama, kendini ifade etme, yorum yapabilme gibi becerilerinin okul öncesi eğitim ile birlikte olumlu yönde geliştiğini belirtmektedir.

Yapılan araştırmaya göre anadili Türkçe olamayan ve okul öncesi eğitim alan öğrencilerin yazı yazmaya ilişkin isteklilikleri almayan öğrencilere göre daha yüksektir. Araştırmaya katılan 35 öğretmenden 23'ü (\%65.71) okul öncesi eğitim almış öğrencilerin çizgi ve boyama çalışmaları yaptığı için küçük kaslarının daha iyi gelişmiş olduğunu ve öğrencilerde yazı yazma isteği oluştuğunu belirtilmiştir. Öğretmenler yazı yazma sürecinde yaşanan zorlukları değerlendirirken; anadili Türkçe olmayan okul öncesi eğitim almamış öğrencilerin Türkçeyi anlama becerilerinin yetersiz olduğunu; bu durumun da öğrencilerin yazma performanslarını düşürdüğünü belirtmiştir. Ayrıca 6 öğretmen \%17.14 anadili Türkçe olmayan ve okul öncesi eğitim almamış öğrencilerin kalem tutma alışkanlığı kazanmadığını, yazı yazma esnasında çabuk yorulduklarını, yazılarını özensiz yazdıklarını, kelime yazarken eksik harflerin bulunduğunu belirtmiştir. Elde edilen bu sonuçlar benzer çalışmalarla paralellik göstermektedir. Yangın (2007) Ankara ilinde 2003-2004 eğitim öğretim yılında okul öncesi eğitim gören altı yaş grubundaki 64 öğrenciye uyguladığı ölçek sonucunda okul öncesi eğitim almış öğrencilerin el becerilerini yeterli düzeyde geliştirdiklerini tespit etmiştir. Pehlivan (2006) Adana ilinde 6 ilköğretim okulunda 60 birinci sınıf öğrencisi ve 15 birinci sınıf öğretmeniyle yaptığı nitel çalışmada; okul öncesi eğitim almayan çocukların el ve parmak hareketleri gelişmediğinden yazma faaliyetlerinde zorlandıklarını, öğretmenlerin hamur yoğurma faaliyetlerine ağırlık verdiğini belirtmiştir. Bilir (2005) makalesinde; okul öncesi eğitim almamış çocukların ellerine kalem verildiğinde, kalemi çok sıkı tuttukları, kalemi hareket ettirirken sanki tüm vücudunu hareket ettirme gerekliliğini düşündüklerini belirtmiştir.

Sonuç olarak yapılan diğer çalışmalar ve bu araştırma doğrultusunda anadili Türkçe olmayan ve okul öncesi eğitim almış öğrencilerin okul öncesi eğitim almamış olan öğrencilere göre, ilk okuma yazma eğitimine başlamak için hazır bulunuşluk düzeylerinin daha iyi olduğu, buna bağlı olarak motivasyonlarının daha yüksek olduğu, kendilerini daha iyi ifade ettikleri için özgüvenlerinin yüksek olduğu, kelime dağarcıklarının gelişmiş olduğu, öğretmenin söylediklerini anladıkları için yazma çalışmalarına daha etkin katıldıkları, yönergeleri daha çabuk anladıkları ve yorumladıkları tespit edilmiştir. Türkçenin az konuşulduğu bölgelerde sınıf öğretmenlerinin ilk okuma yazma eğitimi sürecinde karşılaştıkları sorunları azaltmanın en etkili çözümlerinden birisi de okul öncesi eğitim kurumlarını ve bu kurumlardaki okullaşma oranlarını yaygınlaştırmak olabilir. Bu durum öğretmen-öğrenci, öğretmen-veli iletişiminin artmasında büyük kolaylıklar sağlayabilir.

Anadili Türkçe olmayan bölgelerde okul öncesi eğitim alan öğrencilerin ilk okuma yazma öğrenme başarılarına ilişkin olarak öğretmen algıları onların sınıf mevcuduna göre 
anlamlı bir farklılık göstermemektedir $\mathrm{t}(174)=0,555 ; \mathrm{p}>0,01$. Bu bölgelerde görev yapan ve öğrenci sayıs1 10-24 olan öğretmenlerle öğrenci sayıs1 25-50 olan öğretmenlerin algılarının birbirine benzer olduğu belirlenmiştir. Bu araştırmanın sonucuna göre sınıf mevcudunun az ya da çok olması, bu bölgelerde öğretmenlerin okul öncesi eğitim almış öğrencilere yönelik farklı bir algı geliştirmeleri için gerekçe değildir.

Ana dili Türkçe olmayan bölgelerde okul öncesi eğitim alan öğrencilerin ilk okuma yazma öğrenme başarılarına ilişkin olarak öğretmen algıları görev yeri değişkenine göre anlamlı bir farklılık oluşturmamaktadır $\mathrm{F}(2,173)=1,44, \mathrm{P}>0,01$. Bu araştırmaya göre öğretmenlerin ana dili Türkçe olmayan bölgelerde il, ilçe ya da köy okullarında görev yapmaları bu öğrencilere yönelik farklı bir algı geliştirmeleri için özel bir gerekçe değildir. Fark anlamlı olmamasına karşın köy okullarında çalışan öğretmenlerin $(\bar{x}=171,35)$, il $(\bar{x}=16,70)$ ve ilçede $(\bar{x}=164,49)$ görev yapan öğretmenlere göre daha yüksek bir ortalamaya sahip olması dikkat çekici bir durumdur. Köylerde okul öncesi eğitime ulaşma olanağının daha kısıtlı ve Türkçe bilme durumunun daha düşük düzeyde olması köy öğretmenlerinin ortalamasının biraz daha yüksek olmasına neden olmuş olabilir. Araştırmadan elde edilen sonuçlar doğrultusunda şu öneriler geliştirilmiştir:

Ana dili Türkçe olmayan bölgelerde okul öncesi eğitim kurumlarına gelen öğrencilerin Türkçe dil becerilerini geliştirmek için görsel okuma görsel sunu çalışmalarına özel bir önem verilmelidir. Görsellerin dil öğrenmeye olan katkıları göz önüne alınarak öğrenciler sık sık bu materyallerle eğitim almalıdır.

İlk okuma yazma eğitiminde sınıf öğretmenlerinin kullanma olasılığı olan açıklama ve yönergeler dikkate alınmalı. Okul öncesi eğitimde bunların öğretilmesine öncelik verilmelidir. Gerekirse sınıf öğretmenleri ve okul öncesi eğitim öğretmenleri iletişim halinde olmalıdır.

Ana dili Türkçe olmayan bölgelerde ilk okuma yazma öğretimi sürecinde sınıf öğretmenlerinin yaşadığı sorunların çözümüne katkı sağlamak için okul öncesi eğitim ya zorunlu hale getirilmeli ya da kapsamlı bir şekilde yaygınlaştırılmalıdır.

Ana dili Türkçe olmayan bölgelerde veliler okul öncesi eğitim hakkında bilgilendirilmeli ve bu eğitimin dil öğrenmeye olan katkıları açıklanmalıdır. -İstekli olan okul öncesi öğretmenlerine ve sınıf öğretmenlerine hizmet içi eğitimle bulundukları bölgenin dilini öğrenmeye ilişkin kurslar açılmalıdır. Bu kurslar öğretmen-öğrenci iletişimine katk1 sağlayacağı gibi öğretmen-veli iletişimi de kolaylaştırabilir.

Ana dili Türkçe olmayan bölgelerde okul öncesi ve 1. sınıf öğretmenlerinin -öğrencileri yakından tanıma açısından- iletişim halinde olmaları sağlanmalıdır. Gerekirse bu öğretmenler bir araya gelerek zümre toplantıları düzenlemelidir. Okul yöneticileri ve öğretmenler okul öncesi eğitim almamış öğrenci ve velileriyle yakın görüşme içerisinde bulunmalı ve ögretmenlerin veli ziyareti yapmaları sağlanmalıdır. 


\section{Kaynakça}

Achmet, İ. A. (2005). Yunanistan'da (Batı Trakya'da) ikidilli eğitim veren azınlık okullarında Türkçe ve Yunanca ögrrenim gören ögrrencilerin okuduğunu anlama ve yazılı anlatım becerilerinin değerlendirilmesi. Yayımlanmamış doktora tezi, Ankara Üniversitesi, Ankara.

Aka, M. (2012). Türkiye'de diller ve etnik gruplar. Uluslararası Türkçe Edebiyat Kültür Eğitim Dergisi, 1 (1), 293-297.

Alıcı, M. (2012). Illköğretim düzeyinde iki dilde yazılmış (Türkçe- Almanca) çocuk kitapları üzerine bir içerik incelemesi. Yayımlanmamış yüksek lisans tezi, Hacettepe Üniversitesi, Ankara.

Aslan, Ü., Arslantaş, İ. ve Aslan, İ. (2015). Anadili Türkçe olmayan öğrencilere ilk okuma-yazma öğretiminde öğretmenlerin karşılaştıkları güçlükler. International Journal of Languages' Education and Teaching, $2704-2716$.

Arslanargun, E. ve Tapan, F. (2012). Okul öncesi eğitim ve çocuklar üzerindeki etkileri. Abant İzzet Baysal Üniversitesi Ĕ̈itim Fakültesi Dergisi, 11(2), 219-238.

Aytaş, G. ve Çeçen, M. A. (2010). Ana dili eğitiminde dil bilgisi öğretiminin yeri ve önemi. TÜBAR, 27, 77-89.

Baştürk, R. (2010). Eğitim bilimlerinde yöntem. A. Tanrı̈ŏgren, ve R. Sarpkaya (Ed.) Eğitim bilimine giriş içinde (s. 219-232). Ankara: Anı yayıncılık.

Berlinski, S., Galiani, S. \& Manacorda, M. (2008). Giving children a better start: Preschool attendance and school-age profiles. Journal of Public Economics, 92, 1416-1440.

Bilir, A. (2005). İlköğretim birinci sınıf öğrencilerinin özellikleri ve ilk okuma yazma öğretimi. Ankara Üniversitesi Eğitim Bilimleri Fakültesi Dergisi, 38, 87-100.

Büyüköztürk, Ş. (2012). Sosyal bilimler için veri analizi elkitabı: İstatistik, araştırma deseni, SPSS uygulamalarl ve yorumu. Ankara: Pegem yayınc1lı.

Büyüköztürk, Ş., Kılıç Çakmak, E., Akgün, Ö. E., Karadeniz, Ş. ve Demirel, F. (2012). Bilimsel araştırma yöntemleri. Ankara: Pegem akademi.

Butler, Y. G. ve Hakuta, K. (2004). Bilingualisim and second language acquisition. In K. Bhatia \& W. C. Ritchie (Ed.), . The handbook of bilingualism (p. 114-168). Malden, MA: Blackwell publishing.

Calp, M. (2003). İlk okuma yazma öğretimi. Konya: Eğitim yayınevi.

Çelenk, S. (2008). İlköğretim okulları birinci sınıf öğrencilerinin ilkokuma ve yazma öğretimine hazırlık düzeyleri. Abant İzzet Baysal Üniversitesi Eğitim Fakültesi Dergisi, 8 (1), 83-90.

Damar, M. (2009). Okul öncesi eğitimde dil etkinlikleri. Millî Eğitim, 182, 96-105.

Demir, C. ve Yapıcı, M. (2007). Ana dili olarak Türkçenin öğretimi ve sorunları. Sosyal Bilimler Dergisi, 9 (2), 177-192.

Demirel, Ö. (1999). İlköğretim okullarında yabancı dil öğretimi. İstanbul: Milli eğitim basımevi.

Deretarla Gül, E. ve Bal S. (2006). Anasınıfı öğretmenlerinin okuma yazmaya hazırlık çalışmalarına ilişkin bakış açıları, sınıf içi kullanılan materyal ve etkinliklerle çocukların okuma yazmaya ilgilerinin incelenmesi. Çocuk Gelişimi ve Eğitimi Dergisi, 1(2), 33-51.

Ekinci Vural D. (2012) Okul öncesi eğitimin ilköğretime etkisinin aile katılımı ve çeşitli değisskenler açısından incelenmesi. Yayımlanmamış doktora tezi, Dokuz Eylül Üniversitesi Eğitim Bilimleri Enstitüsü, İzmir.

Ellez, M. (2014). Ölçme araçlarında bulunması gereken özellikler. A. Tanrıöğen, (Ed.), Bilimsel Araştırma Yöntemleri içinde (s. 165-190). Ankara: Anı yayıncılık.

Entwisle, D.R. (1995). The role of schools in sustaining benefits of early childhood programs. The Future of Children, 5(3), 133-144.

Erkan, S. ve Kırca, A. (2010). Okul öncesi eğitimin ilköğretim birinci sınıf öğrencilerinin okula hazır bulunuşluklarına etkisinin incelenmesi. Hacettepe Üniversitesi Eğitim Fakültesi Dergisi (H. U. Journal of Education), 38, 94-106.

Erkinay, H.K. (2012). Genç akademisyenlerin perspektifinden birlikte yaşamak. İstanbul: Da Yayıncılık. 
Fırat, M., Kabakçı Yurdakul, I. ve Ersoy, A. (2014). Bir eğitim teknolojisi araştırmasına dayalı olarak karma yöntem araştırması deneyimi. Eğitimde Nitel Araștırmalar Dergisi-ENAD. 2 (1), 65-86.

Güven, S. ve Karslı, M. D. (2014). Sınıf yönetiminin etkililiğini etkileyen faktörlere ilişkin okul müdürlerinin görüşleri. Dicle Üniversitesi Ziya Gökalp Eğitim Fakültesi Dergisi, 23, 1-24.

Margetts, K. (2003). Children bring more to school than their backpacks: Starting school down under. Journal of European Early Childhood Education Research Monograph, 1, 5-14.

MEB (2013). Okul Öncesi Eğitimi Programı. Ankara. http://tegm.meb.gov.tr Erişim tarihi:08. 11. 2018.

Miles, M. B. \& Huberman, A. M. (1994). Qualitative data analysis: An expanded sourcebook. California: Sage publications.

Oktay, A. (2002). Yaşamın sihirli yılları: Okul öncesi dönem. İstanbul: Epsilon Yayıncılık.

Oktay, A. (2003). 21. yüzylla girerken dünyada yaşanan değişimler ve erken çocukluk eğitimi. Erken çocuklukta gelişim ve eğitimde yeni yaklaşımlar (Ed. M. Sevinç). İstanbul: Morpa Kültür Yayınları, s. 18-30.

Özbay, M. ve Melanlıoğlu, D. (2004). Türkçe eğitiminde kelime hazinesinin önemi. Yüzüncü Yıl Üniversitesi Eğitim Fakültesi Dergisi, 5 (1), 30-45.

Parlak, H. (2014). Avustralya'daki Türk ailelerin anadil edinimi üzerindeki rolü. Sosyal Politika Çalışmaları Dergisi, 3(2 ), 9-31.

Pehlivan, D. (2006). Okul öncesi eğitim alan ve almayan ögrencilerin ilk okuma yazmaya geçiş sürecinin, ögretmen ve ögrenci görüşleri doğrultusunda değerlendirilmesi. Yayımlanmamış yüksek lisan tezi. Çukurova Üniversitesi, Sosyal Bilimler Enstitüsü, Adana.

Sapsağlam, Ö. (2013). Değerlendirme boyutlarıyla okul öncesi eğitim programları (1952- 2013). Uluslar arası Türk Eğitim Bilimleri Dergisi, 1, 63-73.

Susar Kırmızı, F., Özcan, E. ve Şencan, D. (2016). Türkçenin az konuşulduğu bölgelerde ilk okuma yazma sürecinde karşılaşılan sorunlara ilişkin öğretmen görüşleri. Uluslararası Türkçe Edebiyat Kültür Eğitim Dergisi (TEKE), 5 (1), 412-445.

Şahin, A., Susar Kırmızı, F. ve Salgut, E. (2016). Okul öncesi eğitimin ilk okuma yazma sürecine etkisi. F. Susar Kırmızı. ve E. Ünal, E. (Ed.) İlk okuma yazma öğretimi içinde (s. 291-320), Ankara: Anı yayıncılık.

Şimşek Bekir, H. ve Temel, Z. F. (2006). Almanya'da okul öncesi eğitim kurumlarında devam eden 5-6 yaş grubu Türk çocuklarına uygulanan dil eğitim programının dil gelişim düzeyine etkisi. Gazi Üniversitesi Endüstriyel Sanatlar Eğitim Fakültesi Dergisi, 18, 14-27.

Taşkaya, S. M. (2017). Ana dili Türkçe olmayanlara ilk okuma yazma öğretimi. F. Susar Kırmızı, E. Ünal (Edt.) Illk Okuma Yazma Öğretimi içinde (207-232). Ankara: Anı yayıncılık.

Tuğluk, İ. H., Kök M., Koçyiğit, S., Kaya, H. İ. ve Gençdoğan, B. (2008). Okul öncesi öğretmenlerinin okuma- yazma etkinliklerini uygulamaya ilişkin görüşlerinin değerlendirilmesi. Atatürk Üniversitesi Kazım Karabekir Eğitim Fakültesi Dergisi (KKEFD), 17, 72-81.

Tulu, Y. (2009). Ana dili Türkçe olan ve ana dili Türkçe olmayan (iki dilli) 4-7 yaş çocukların dil düzeylerine etki eden faktörlerin incelenmesi. Yayımlanmamış yüksek lisans tezi, Selçuk Üniversitesi, Konya.

Yangın, B. (2007). Okul öncesi eğitim kurumlarındaki altı yaş çocuklarının yazmayı öğrenmeye hazır bulunuşluk durumları. Hacettepe Üniversitesi Ĕ̆itim Fakültesi Dergisi, 32, 294-305.

Yapıcı, M. (2004). İlköğretim dilbilgisi konularının çocuğun bilişsel düzeyine uygunluğu. İlköğretimOnline, 3(2), 35-41.

Yapıcı, M. ve Ulu, F. B. (2010). İlköğretim 1. sınıf öğretmenlerinin okul öncesi öğretmenlerinden beklentileri. Kuramsal Ĕgitimbilim, 3(1), 43-55.

Yıldırım, A. ve Şimşek, H. (2016). Sosyal bilimlerde nitel araştırma yöntemleri, Ankara: Seçkin yayıncilık.

Yılmaz, N. (2003). Türkiye'de okul öncesi eğitim. Erken Çocuklukta Gelişim ve Eğitimde Yeni Yaklaşımlar (Ed. M. Sevinç). İstanbul: Morpa Kültür Yayınları, s. 12-17. 
Yılmaz, F., \& Şekerci, H. (2016). Ana dil sorunsalı: Sınıf öğretmenlerinin deneyimlerine göre ilkokul öğrencilerinin yaşadıkları sorunlar. Eğitimde Nitel Araştırmalar Dergisi - Journal of Qualitative Research in Education, 4(1), 47-63, http://dx.doi.org/10.14689/issn.2148-2624.1.4c1s3m

Yoleri, S. ve Tanış, H. M. (2004). İlkokul birinci sınıf öğrencilerinin okula uyum düzeylerini etkileyen değişkenlerin incelenmesi. Sosyal Bilimler Enstitüsü Dergisi Karabük Üniversitesi, 4(2), 130141. 


\section{Extended Abstract}

\section{Introduction}

The children who are non-Turkish and have not taken a pre-school education come across many enormous difficulties when they start primary school. These children start primary school before acquiring the required level of literacy skills. The child has great problems in terms of distinguishing words, using the words appropriately, making complete and correct sentences, asking questions about the subject of his/her interest and expressing his/her wishes confidently. The purpose of this research is to determine the problems experienced in the learning process of initial literacy by the students that are non-Turkish and have not taken a pre-school education according to the views of the teachers.

\section{Methods}

In this study, the mixed method in which the qualitative and quantitative research are proceeded together is conducted. "Grounded design" among the mixed methods was preferred. The quantitative and qualitative data were collected at the same time in the research process. However, the evaluation of qualitative data was given more priority.

This research was carried out through the access network that is accessible to the teachers working for the NEM. The "open-ended question questionnaire" and the "Scale for Tendency of Teachers towards Effect of Pre-school Education on Learning Process of Initial Literacy for Non-Turkish Students (STTEPL)" generated by the researchers were implemented in collecting data. Whereas STTEPL was filled by 176 teachers (female $=79$; male $=97$ ), 35 teachers from the same group (female $=21$, male $=14$ ) answered the open-ended questionnaire. 3 themes and 7 codes were obtained as a result of content analysis applied to the qualitative data. 2 sub-codes based on the differences within the codes itself were revealed. The most commonly reported code is the code of "qualifications". $31(88.57 \%)$ teachers expressed their thoughts related to this code. The least-reported codes are the sub-codes of "advanced language skills, socialization, and vocabulary".

\section{Findings}

Of the 35 teachers participating in the study, 15 (42.85\%) teachers expressed that pre-school education had positive effects on the readiness level of the students. Pre-school education enables children to gain the skills to express themselves, to understand and to apply the instructions, as well as to ensure the development of school culture in children. When the statements of the teachers were examined, it was concluded that $4(11,42)$ of the 35 teachers participating in the research reported their positive views on the effect of preschool education on the motivation levels of the students. Of the 35 teachers who participated in the study, 26 (74.28\%) teachers stated that students who had received pre-school education understood the instructions more easily, therefore they acted in accordance with the purpose of the instruction and that they could establish the cause-effect relationship in an easier way. When the findings of the study were examined, 6 teachers $(17.14 \%)$ expressed that there were difficulties in writing exercises in the students who have not taken pre-school education. 


\section{Discussion}

The perceptions of the teachers about the success of the students with pre-school education do not significantly varied in terms of the variables of classroom size, and place of duty of the teachers. According to the teachers, the students with pre-school education start primary school with the necessary knowledge and skills necessary for literacy education. This supports their ability to speak Turkish and improves their competence to communicate with others. Students whose language skills are not sufficiently developed are not at the expected level in interpreting visuals. According to the opinions of the teachers, the students encounter many visuals during the process of pre-school education. Moreover, the studies on the interpretation of these visuals are included. This situation both contributes to the increase in the skill to speak Turkish of the students and enables the ability of visual reading and visual presentation to reach a certain level. 
EK A

\section{Ana Dili Türkçe Olmayan Öğrencilerde Okul Öncesi Eğitimin İlk Okuma Yazma Öğrenme Sürecine Etkisine İliş̧kin Öğretmenlerin Eğilimleri Ölçeği (ADILLKÖ)}

\section{MADDELER}

Okul öncesi eğitim almış öğrenciler almamış öğrencilere göre;

1. Boyama çalışmalarında daha başarılıdır.

2. Kendini daha iyi ifade edebilmektedir.

3. İletişime daha açıktır.

4. Okuma performansında daha iyidir.

5. Türkçeyi daha iyi konuşabilmektedir.

6. Küçük kas gelişiminde daha iyidir.

7. Okuma eğitimine daha isteklidir.

8. Görsel okuma çalışmalarında daha iyidir.

9. Görsellerden yola çıkarak öykü anlatmada daha başarılıdır.

10. Arkadaşlarını Türkçe konuşmaya teşvik eder.

11. Türkçe olarak öğretmen ile daha kolay iletişim kurabilir.

12. Okula uyum sürecini daha kolay geçirmektedir.

13. Harflerin yazılışlarını kavramada daha başarılıdır.

14. Yazmaya daha isteklidir.

15. Kalemi daha doğru tutmaktadır.

16. Dinleme becerisinde daha iyidir.

17. Sözel yönergeleri daha iyi anlayabilmektedir.

18. Verilen sözel yönergelere daha hızlı dönüt verebilmektedir.

19. Yorum yapma becerisi daha iyidir.

20. Özgüveni daha yüksektir.

21. Derste yapılan etkinliklere daha çok ilgi göstermektedir.

22. Daha geniş bir sözcük dağarcığına sahiptir.

23. Türkçe telaffuzda daha iyidir

24. Türkçe konuşmayı öğrenmede daha isteklidir.

25. Yazıları beklenen şekilde yazmada daha başarılıdır.

26. Türkçeyi daha iyi anladığı için ödevlerini yapmada daha gayretlidir.

27. Etkinliklerde öğretmene zaman kazandırmaktadır.

28. Söyleneni anladığından dolayı ders araç-gereçlerini eksiksiz getirmektedir.

29. Okuduklarına yeni yorumlar getirebilmektedir.

30. Kitap okumada daha isteklidir.

31. Okula gelmede daha isteklidir.

32. Türkçe konuşmaları anlama becerisinde daha iyidir.

33. Türkçe öğrenmek için ek zamana gereksinim duymamaktadır.

34. Dinlediklerini anladığı için sınıfta sorun çıkarmamaktadır.

35. Okuduğu metinlerdeki anlamı yakalamada daha başarılıdır.

36. Öğretmenin çok fazla açıklayıcı ifade kullanılmasına gerek kalmamaktadır.

37. Bilmecelere yanıt vermede daha başarılıdır.

38. Tekerleme söylemede daha başarılıdır.

39. Türkçedeki temel kavramları bilerek gelmektedir. 